REVIEW ARTICLE

\title{
Bioactive Peptides from Legumes as Anticancer Therapeutic Agents
}

\author{
González-Montoya Marcela ${ }^{1}$, Cano-Sampedro Eden ${ }^{1}$ and Mora-Escobedo Rosalva ${ }^{1 *}$
}

${ }^{1}$ Departamento de Ingeniería Bioquímica, Campus Zacatenco, Unidad Profesional "Adolfo López Mateos", Ciudad de México

*Corresponding author: Rosalva Mora-Escobedo, Departamento de Ingeniería Bioquímica, Escuela Nacional de Ciencias Biológicas Instituto Politécnico Nacional, Campus Zacatenco, Unidad Profesional "Adolfo López Mateos", Calle Wilfrido Massieu s/n. 07738, Ciudad de México, México, Tel: +52-55-57296000,Ext: 57872, E-mail: rosalmorae@gmail.com

\begin{abstract}
Food proteins are a source of nutraceutical and bioactive peptides that promote health and prevent diseases. Legume seed proteins have been widely studied to produce peptides (protein fragments) with a diversity of biological activities. Generally, these Bioactive Peptides (BPs) are encrypted in proteins but can be released by modifications or cleavage from original protein by means of enzymes during gastrointestinal transit or processes as fermentation, germination, heating and pressure. Storage proteins, lectins and protease inhibitors have been reported to be sources of BPs. These peptides are capable of generating a physiological effect against cancer cells and can induce cell death by different mechanisms like apoptosis, affecting the tubulin-microtubule equilibrium and inhibiting angiogenesis. Finally, anticancer therapy based on legume-derived peptides could play a significant role in the pharmaceutical and nutraceutical industry due to the benefits as functional ingredients which improve the life quality of patients or reduce the risk of cancer.
\end{abstract}

\section{Keywords}

Food proteins, Legumes, Bioactive peptides, Anticancer peptides, Peptide-based anticancer therapy

\section{Introduction}

The number of new cases of cancer is expected to rise by about $70 \%$ over the next two decades. This disease is the second leading cause of death worldwide and it was responsible for 8.8 million deaths in 2015 . The main types of diagnosed cancers are: pulmonary, gastric, hepatic, colorectal, breast and cervical [1,2]. Nowadays, it is well known that nutrition and health are closely related and there is evidence regarding the ability of foods and their components to reduce disease risks or enhance the overall quality of life [3].
Legumes or Fabaceae family are a good source of bioactive compounds as proteins. The major storage proteins of legume seeds are oligomeric globulins: $7 \mathrm{~S}$ and $11 \mathrm{~S}$ protein fractions. The $7 \mathrm{~S}$ fraction forms trimmers of about $150 \mathrm{kDa}$, which are stabilized by hydrophobic interactions, electrostatic and hydrogen bonds; while $11 \mathrm{~S}$ proteins are hexamers of about $450 \mathrm{kDa}$. Acidic and basic chains are associated by disulfide bridges [4]. Some bioinformatics tools can provide information with anticancer sequences from legumes. Also, biotechnological processes as fermentation, germination, extrusion and ultra-high pressure can generate bioactive peptides with a wide range of physiological effects as anticancer properties.

\section{Food proteins and bioactive peptides}

Food proteins are one of the macromolecules that have been most widely studied as a source of Bioactive Peptides (BPs) [5]. BPs are amino acid sequences released from parent proteins via cleavage or modifications in the original protein and are involved in several body functions $[6,7]$. BPs may be liberated from food proteins throughout the intestine and can display bioactivity in the small and large bowel. However, given that most food proteins are degraded during their transit through the small intestine, and since microbial activity predominantly occurs in the large intestine, the release by microbial enzymes during digestion is conferred to proteins reaching this site of the intestine [8].

The size of BPs generally ranges between 2 and 20 amino acid residues [5]. These fragments of protein have shown a diversity of biological activities such as antioxidant, anti-inflammatory, anti-hypertensive, anti 


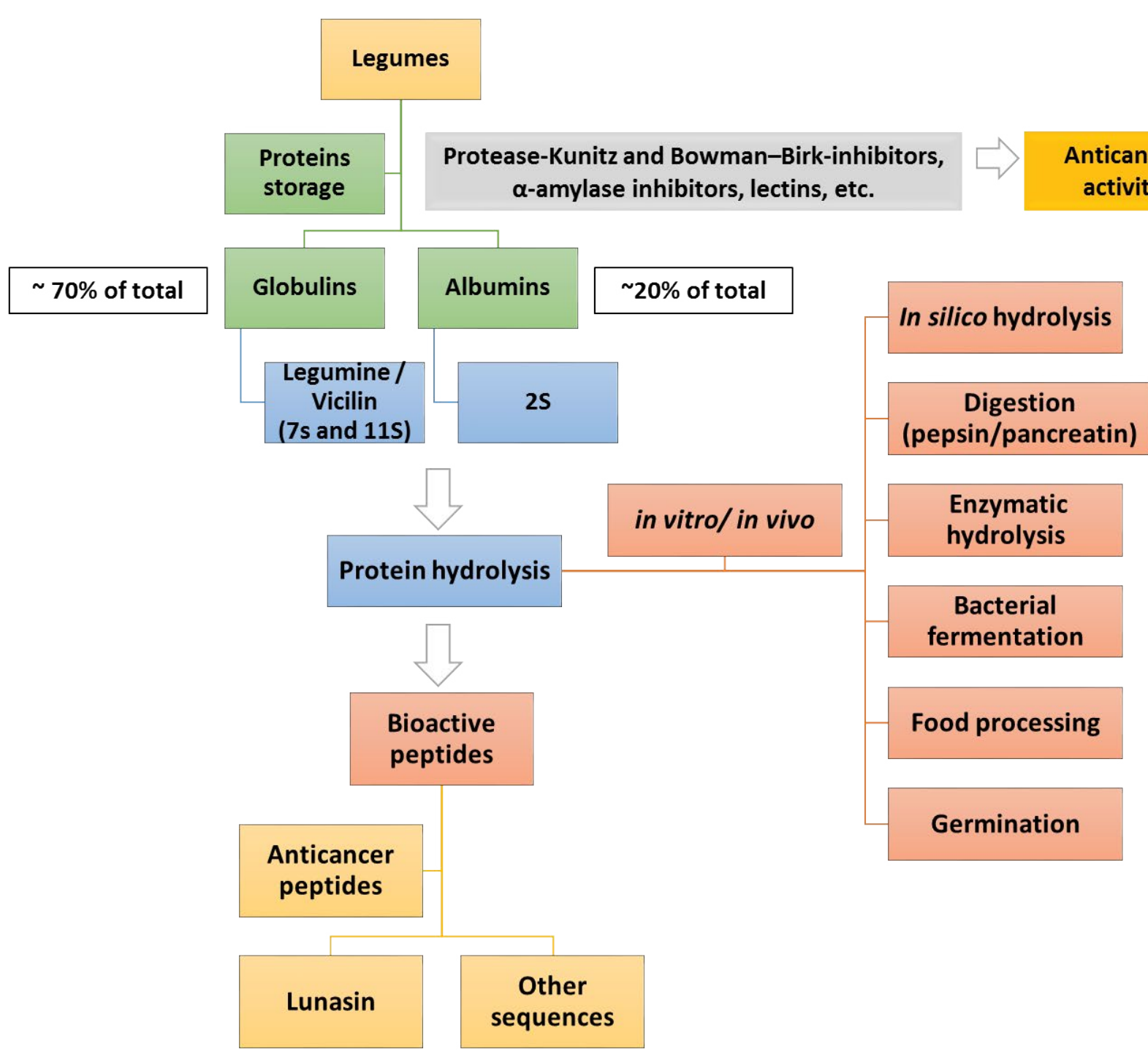

Figure 1: Bioactive peptide production from legume sources as anticancer agents.

proliferative, anticancer, anti-coagulant, anti-cholesterolemic, hypoglycemic, anti-obesity, calcium-binding, and immunomodulatory. Recent studies have described a large number of BPs with nutraceutical and pharmaceutical value, which are obtained from several sources divided mainly into two groups: animal (milk, marine organism, meat, etc.) and vegetable (cereals, seeds, legumes, etc) proteins. Currently, BPs or protein hydrolysates can be commercialized as nutraceutical products or functional ingredients [6].

\section{Bioactive peptides production}

BPs are released from their encrypted protein by enzymes during gastrointestinal transit, by fermentation, thermal processing or additional treatments (Figure 1). Some of the most common ways to obtain BPs from legume sources avoiding the use of only high-temperature treatments are described in this review.

In silico analysis: In silico analysis, can helps to predict a wide range of parameters to obtain BPs and evaluate the biological activities. BIOPEP is a Bioactive Peptide sequence database integrated with a program that allows classifying food proteins as potential sources of BPs. This database also contains profiles of biologically active protein fragments. The quantitative descriptors obtained might have a potential for application of the biological activity of proteins as potential BPs precursors. Such potential may be as follows: prediction of bonds susceptible to hydrolysis by endopeptidases and specific sites susceptible to proteolytic cleavage in protein chains, secondary structure prediction and physicochemical characteristics based on amino acid sequence [9]. A legume-specific protein database (LegProt) has also been created. It contains sequences from seven legume species, such as Glycine max, Lotus japonicus, Medicago sativa, Medicago truncatula, Lupinusalbus, Phaseolus vulgaris, and Pisum sativum. The database consists of amino acid sequences translated from predicted gene models and 6-frame translations of tentative consensus sequences assembled from expressed sequence tags. This was probed using mass spectral data for protein identification and identification success rates were compared to the NCBI database [10].

Enzymatic hydrolysis: Partial hydrolysis of protein structure using protease work at moderate $\mathrm{pH}$ and temperature conditions $\left(\mathrm{pH} 5-9 ; 40-60{ }^{\circ} \mathrm{C}\right)$ may contribute to the development of new peptide fractions with nu- 
tritional or functional characteristics [11]. To assess if BPs are produced naturally during gastrointestinal digestion, in vitro digestions are commonly carried out with proteases (pepsin, trypsin, chymotrypsin, and pancreatin). Researchers have also performed enzymatic hydrolysis with microbial or plant enzymes, such as alcalase, flavourzyme, papain and bromelain, to obtain bioactive sequences [6,11-15].

Fermentation: Solid and liquid fermentations are current processing techniques used to preserve and enhance the nutritional quality and health-promoting properties of legumes. The type of microorganism involved plays a key role during the process. Bacillus subtilis has been used in the manufacturing of soybean fermented products. Lactic acid bacteria have also been traditionally used in legume fermentation since they are naturally present in legume grains. The lactic acid fermentation of legumes with Lactobacillus can enhance the production of bioactive compounds, providing health benefits beyond basic nutrition [16]. Fermentation can also result in the reduction of anti-nutritional components such as protease inhibitors, phytic acid, urease, and oxalic acids [14].

Germination: Germination has been used as a natural hydrolytic process that is generated by intrinsic enzymes. The amount and composition of nutrients in food legumes are influenced by the germination process depending on soak time, humidity, temperature and time as well as cultivars [17]. This process generates changes in the secondary metabolite distribution and mobilizes the reserve proteins stored in the cotyledon protein bodies, producing intermediate molecular weight peptides. Mora-Escobedo, et al. [15] showed that germination can improve the anti-proliferative effect of soybean protein on HeLa and C-33 cervical cancer cells. Peptides generated during germination can alter cell signaling pathways and cause apoptosis. Histologic examination of tumor tissues of nude mice implanted with HeLa cells showed that the consumption of soy products increases both apoptotic and necrotic death [18].

Food processing: Food protein processing by both extrusion and Ultra-High Pressure (UHP) is widely used to obtain legume seed products. Extrusion is a high-temperature-short-time food processing that has been used to get pre-cooked flours with high nutritional value and increase some biological activities [19]. UHP processing is a non-thermal process in which foods are subjected to high isostatic pressures (100-1000 $\mathrm{MPa}$ ) at room temperature. It can affect protein conformation and lead to denaturation, aggregation or gelation, depending on the protein system, applied pressure, temperature, and time of treatment. Low pressures usually induce reversible changes, as dissociation of protein-protein complexes and conformational changes. These changes can generate protein or peptide sequences with biological effects [20]. However, food processing should be done in a controlled manner because sometimes it can significantly modify amino acid side chains. These modifications also have important implications and might influence cancer cells via RAGE (receptors for advanced glycation end products) and other receptors [21]. Advanced Glycation End Products (AGEs) are reactive metabolites produced during the breakdown of sugar and amino acids through the Maillard reaction. AGEs can be accumulated in tissues and organs over time and contribute to the development and complications of chronic diseases as cancer [22]. The presence of AGEs in human tumors was first demonstrated in larynx, breast and colon tumors. The exogenous AGE treatment of breast and immortalized prostate cancer cell lines promotes cell growth, migration and invasion. Dietary-derived AGE carboxymethyl-lysine has also been associated with increased risk of pancreatic cancer. AGEs levels were significantly elevated in both serum and tumor with the highest accumulation occurring in more aggressive tumors [23].

\section{Legume Proteins as Source of Anticancer Peptides}

Fabaceae or Leguminosae family are commonly named legumes; in this review article, the term "legumes" is used to describe the seeds of these plants. Nutritionally, legumes are important source of food proteins, which are deficient in sulfured amino acids and tryptophan, but possess high amounts of lysine, arginine, glutamic and aspartic acid, as compared with cereals grains [6]. The main fraction of proteins in legume seeds are storage proteins, which are classified by solubility in albumins, globulins, prolamins, and glutelins. Albumins represent $10 \%-20 \%$ of legume proteins [24], while globulins represent $70 \%$ of the total amount of proteins in legumes. This fraction is soluble in saline solutions specially legu$\min$ (7S and 11S) and vicilin [25]. The anticancer effects of legumes have been extensively explored and studies have described that a higher intake of legumes significantly reduced the risk of colorectal adenoma [26,27]. Researchers have also described the low glucose index of legumes, which leads to a reduced risk of developing chronic diseases as diabetes, cardiovascular diseases and cancer. Legumes show a wide range of bioactive compounds, such as isoflavones, saponins, lectins and others. However, we have focused this review on proteins as well as bioactive peptides derived from them. A list of some BPs obtained from legume proteins, which have been reported to have a potent anticancer activity, are shown in Table 1.

\section{Soybeans}

Soybean (Glycine max) is a functional food due to its high protein content, fat composition, and isoflavones, thus having beneficial physiological effects to human health. Nowadays, there is an increasing interest in incorporating soybeans or soy proteins like functional ingredients in foods [28]. Dietary proteins from soybeans have been shown to offer health benefits in 
Table 1: Anticancer peptides from legume sources and action mechanisms proposed.

\begin{tabular}{|c|c|c|c|c|c|}
\hline $\begin{array}{l}\text { Legume } \\
\text { source }\end{array}$ & Peptide name or sequence & $\begin{array}{c}\text { In vitro/in } \\
\text { vivo models }\end{array}$ & $\begin{array}{l}\text { Doses tested/ } \\
\text { IC50 }\end{array}$ & Anticancer action mechanism & Reference \\
\hline $\begin{array}{l}\text { Soybean } \\
\text { (Glycine max) }\end{array}$ & $\begin{array}{l}\text { IBB1 and IBB2 (Bowman- } \\
\text { Birk isoinhibitors) }\end{array}$ & HT-29 & $\begin{array}{l}39.9 \mu \mathrm{M} \text { and } \\
48.3 \mu \mathrm{M}\end{array}$ & $\begin{array}{l}\text { Inhibition of serine proteases and } \\
\text { cells becoming blocked in the G0- } \\
\text { G1 phase. }\end{array}$ & [41] \\
\hline Soybean & Lunasin & С3H10T1/2 & $2 \mu \mathrm{M}$ & $\begin{array}{l}\text { Inhibits chemical carcinogen- } \\
\text { induced transformation and } \\
\text { selectively induces apoptosis in } \\
\text { transfected cells but not in non- } \\
\text { transformed cells. }\end{array}$ & [32] \\
\hline Soybean & Lunasin & SENCAR & $250 \mu \mathrm{g} /$ week & $\begin{array}{l}\text { Reduces skin tumor incidence } \\
\text { by } 70 \% \text {, decreases tumor yield/ } \\
\text { mouse, and delays the appearance } \\
\text { of tumors by } 2 \text { weeks relative to the } \\
\text { positive control. }\end{array}$ & [32] \\
\hline Soybean & $\begin{array}{l}\text { ASKWQHQQDS } \\
\text { CRKQLQGVNL } \\
\text { TPCEKHIMEK } \\
\text { IQGRGDDDDD } \\
5 \text { kDa Lunasin-like peptide }\end{array}$ & Raw 264.7 & $10-50 \mu \mathrm{M}$ & $\begin{array}{l}\text { Inhibition of pro-inflammatory } \\
\text { markers (IL-6, IL-1 } 1 \beta, N F-k B \text {, } \\
\text { COX-2, iNOs, etc.) and aberrant } \\
\text { inflammation is associated with the } \\
\text { development of chronic diseases } \\
\text { such as cancer. }\end{array}$ & [61] \\
\hline Soybean & $\begin{array}{l}\text { X-Met-Leu-Pro-Ser-Tye-Ser- } \\
\text { Pro-Tyr }\end{array}$ & P388D1 & $\begin{array}{l}0.16 \mathrm{mg} / \mathrm{ml} \text { and } \\
1 \mathrm{mg} / \mathrm{ml}\end{array}$ & $\begin{array}{l}\text { Cytotoxicity and cell cycle arresting } \\
\text { at G2/M phase. }\end{array}$ & [62] \\
\hline $\begin{array}{l}\text { Common bean } \\
\text { (Phaseolus } \\
\text { vulgaris) Legumi } \\
\text { Secchi cultivar }\end{array}$ & $\begin{array}{l}\text { ANDISFNFVRFNETNLILGG } \\
\text { i }\end{array}$ & MCF-7 & $0.2 \mu \mathrm{M}$ & $\begin{array}{l}\text { Cell cycle arrest in G2/M phase, } \\
\text { phosphatidylserine externalization } \\
\text { and mitochondrial membrane } \\
\text { depolarization. }\end{array}$ & [63] \\
\hline $\begin{array}{l}\text { Common } \\
\text { bean Azufrado } \\
\text { Higuera and } \\
\text { Bayo Madero } \\
\text { cultivars }\end{array}$ & $\begin{array}{l}\text { GLTSK, LSGNK, GEGSGA, } \\
\text { MPACGSS, MTEEY }\end{array}$ & НСТ-116 & $\begin{array}{l}0.53 \mathrm{mg} / \mathrm{ml} \text { and } \\
0.51 \mathrm{mg} / \mathrm{ml}\end{array}$ & $\begin{array}{l}\text { Both cultivars increased significantly } \\
\text { the expression of p53 in HCT116 by } \\
76 \% \text { and } 68 \% \text {. }\end{array}$ & [33] \\
\hline $\begin{array}{l}\text { Common beans } \\
\text { Extra long } \\
\text { Autumn Purple } \\
\text { Bean cultivar }\end{array}$ & ANEIYFSFQRFNETNLILQR & $\begin{array}{l}\text { CNE-1, } \\
\text { CNE-2 and } \\
\text { HNE-2 MCF- } \\
7 \text { HepG2 }\end{array}$ & $\begin{array}{l}725 \mu \mathrm{M}, 735 \mu \mathrm{M}, \\
396 \mu \mathrm{M}, 741 \mu \mathrm{M} \\
\text { and } 83 \mu \mathrm{M}\end{array}$ & $\begin{array}{l}\text { Inhibit the proliferation of human } \\
\text { tumor cells by inducing the } \\
\text { production of apoptotic bodies and } \\
\text { nitric oxide. }\end{array}$ & [64] \\
\hline $\begin{array}{l}\text { Chickpea (Cicer } \\
\text { arietinum) }\end{array}$ & ARQSHFANAQP & $\begin{array}{l}\text { MCF-7 } \\
\text { and MDA- } \\
\text { MB-231 }\end{array}$ & $\begin{array}{l}2.38 \mu \mathrm{M} \text { and } \\
1.50 \mu \mathrm{M}\end{array}$ & $\begin{array}{l}\text { The peptide effectively inhibited the } \\
\text { proliferation of breast cancer cells } \\
\text { increasing the level of p53 trough } \\
\text { binding prediction with molecular } \\
\text { docking. }\end{array}$ & [65] \\
\hline $\begin{array}{l}\text { Pea (Pisum } \\
\text { sativum) }\end{array}$ & $\begin{array}{l}\text { TI1B (Bowman-Birk } \\
\text { isoinhibitor) }\end{array}$ & HT-29 & $31 \mu \mathrm{M}$ & $\begin{array}{l}\text { Reduction in the viability assay on } \\
\text { cancer cells. }\end{array}$ & [41] \\
\hline $\begin{array}{l}\text { Fava Bean } \\
\text { (Vicia faba) }\end{array}$ & $\begin{array}{l}\text { VFTI-G1 (Bowman-Birk type } \\
\text { trypsin inhibitor) }\end{array}$ & HepG2 & $30 \mu \mathrm{M}$ & $\begin{array}{l}\text { Induce nuclear morphological } \\
\text { changes of cells and the reduction } \\
\text { of viable cells and increased } \\
\text { chromatin condensation and } 60 \% \text { of } \\
\text { cells underwent apoptosis. }\end{array}$ & [43] \\
\hline $\begin{array}{l}\text { Lentil (Lens } \\
\text { culinaris) }\end{array}$ & (Bowman-Birk isoinhibitors) & HT-29 & $19 \mu \mathrm{M}$ & $\begin{array}{l}\text { Inhibit cell proliferation of colon } \\
\text { cancer cells in a dose-dependent } \\
\text { manner related to their intrinsic } \\
\text { abilities to inhibit serine proteases. }\end{array}$ & [46] \\
\hline
\end{tabular}

vivo and in vitro either as intact proteins or in partially digested forms. The oral administration and absorption of soy-derived BPs induce antioxidant, anti-microbial, anti-hypertensive, anticancer, and immunomodulatory effects $[28,29]$. For this reason, there is a great interest in the therapeutic potential of soy protein hydrolysates and their subsequent incorporation to functional foods [30]. Robles-Ramírez, et al. [18] evaluated the effect of germinated soy protein on the growth of HeLa cervical cancer cells in female athymic mice. They observed that tumor volumes were reduced by $44.6 \%$ with the protein of non-germinated soybean and $98.9 \%$ with the protein of two-day germinated soybean after a five-week treatment. González-Montoya, et al. [31] evaluated the antioxidant and anti-proliferative effects of three peptide fractions of germinated soybeans on breast and cervical cancer cell lines. The highest effect was obtained with HeLa, Caski, and MDA-MB-231 cancer cells. Apoptotic indices for all cancer cells lines showed above $50 \%$ of apoptotic cell after $8 \mathrm{~h}$ of exposure. 
Lunasin (43 amino acid residues), a leader anticancer peptide isolated from soybeans and others legumes, contains nine asparagine (D) residues and the Arginine-Glycine-Asparticacid (RGD) cell adhesion motif at its carboxyl end. This peptide inhibits chemical carcinogen-induced transformation of murine fibroblast cells in to cancerous foci. Lunasin induces selective apoptosis, mostly in cells undergoing transformation, by preventing histone acetylation. It also induces apoptosis in E1A-transfected cells, but not in non-transformed cells [32]. Lunasin can be internalized by RGD cell adhesion motif and it preferentially binds to deacetylate histone $\mathrm{H} 4$ in vitro while it inhibits histone $\mathrm{H} 3$ and $\mathrm{H} 4$ acetylation in vivo in presence of a histone deacetylase inhibitor [32].

\section{Common beans}

Common bean (Phaseolus vulgaris) consumption is part of the traditional diet in many countries around the world. They are an excellent source of proteins (20-25\%) since they are constituted mainly of globulins, albumins and glutelins [12]. Luna, et al. [33] found that two cultivars (Azufrado-Higuera and Bayo-Madero) increase the expression of p53 in HCT-116 human colorectal cancer cells, leading to modifications of markers associated with cell cycle arrest or apoptosis. The research group characterized some peptide sequences of protein hydrolysates, which may be responsible for the anticancer effect. Fang, et al. [34] reported that a dimeric lectin from Phaseolus vulgaris cv. blue tiger king exhibits selective toxicity to human hepatoma HepG2 cells and lacks significant toxicity on normal liver WRL68 cells thus they consider this lectin as a candidate for cancer treatment. Additionally, Sun, et al. [35] demonstrated the anti-proliferative activity of trypsin inhibitors from $P$. vulgaris $\mathrm{cv}$. withe cloud bean against human leukemia L1210 cells.

\section{Chikpeas}

Chickpea (Cicer arietinum) is the third most important pulse crop worldwide based on total production. There are two main chickpea cultivars grown around the world: Desi and Kabuli [36]. Magee, et al. [37] described that chickpea and other plant-derived protease inhibitors can reduce breast and prostate cancer cell proliferation in vitro. Kumar, et al. [38] evaluated the cytotoxic activity of C-25 protein from Cicer arietinum on KB oral cancer cell line. The protein reduced cell proliferation at IC50 of $37.5 \mu \mathrm{g} / \mathrm{ml}$ with no toxic effect on normal human peripheral blood mononuclear cells.

\section{Peas}

Pea (Pisum sativum) constitutes approximately 25 million hectares of grain production worldwide [39]. Pea seeds contain about $22-23 \%$ proteins. Around $80 \%$ of pea proteins are globulins and albumins: albumins represent $18-25 \%$ and globulins $55-65 \%$ of total pro- teins [40]. A diet high in dry pea has been demonstrated to be effective in lowering the incidence of colon cancer, type-2 diabetes, LDL-cholesterol and heart disease [36]. Clemente, et al. [41] described the anti-proliferative effect of the Bowman-Birk Inhibitor (BBI) isoform of pea (TI1B) on HT-29 colon cancer cells, which is mediated through proteases inhibition.

\section{Faba}

Faba beans (Vicia faba) are among the most ancient plants in pulse crops [42]. Faba proteins mainly consist of globulins and represent $24-32 \%$ of the faba bean weight. Leon-Espinosa, et al. [13] demonstrated the hypocholesterolemic and anti-carcinogenic effect of fava bean protein hydrolysates in a colon cancer mice model. Other faba proteins as favin, a Bowman-Birk type trypsin inhibitor (VFT1-G1), and other peptidic protease inhibitors, have been described to possess anti-proliferative activity toward HepG2 hepatoma cells by inducing chromatin condensation and cell apoptosis $[43,44]$.

\section{Lentils}

Lentil (Lens culinaris) is among the oldest pulse crops by humans and has a steadily increasing global consumption. The annual production of lentils increased from 4 to 5 million tons between 2009 and 2010 [45]. Four isoforms of $\mathrm{BBI}$ have previously been isolated from lentil seeds. Caccialupi, et al. [46] reported that lentil BBI showed anti-proliferative properties in human colon cancer cells.

\section{Lupins}

The seed or grains of domesticated Lupinus species is generically called lupin and has very good nutritional properties, with one of the highest protein levels among legumes and an excellent amino acid profile [47]. Lupins are widely used in animal feeding and as a food ingredient [48]. Millán, et al. [49] showed the effect of two different Lupine Protein Hydrolysates (LPHs) in a THP-1-derived macrophage inflamation model. Inflammation can contribute to several acute and chronic diseases such as cancer. The $\mathrm{LPHs}$ were obtained by enzymatic hydrolysis using Izyme AL and Alcalase 2.4 L. THP-1-derived macrophages exhibited attenuated expression of pro-inflammatory cytokines (Tumour Necrosis Factor (TNF), IL-6, IL-1 3 ) and increased expression of anti-inflammatory marker genes (Chemokine (C-C motif) ligand 18 (CCL18)) relative to control. The anti-inflammatory effect of both hydrolysates improve M2 polarization by quenching C-C Chemokine Receptor Type 2 (CCR2) expression and migratory capacity. Furthermore, LPHs significantly decreased nitric oxide production [49]. Investigations on anticancer peptides from lupins has not been widely reported, so it is an interesting research field to explore.

\section{Peptide-Based Therapies as Anticancer Agents and Action Mechanisms}

Anticancer peptide therapy is an emerging field that 
uses BPs to kill cancer cells. BPs can be easily designed using bioinformatics tools to target some protein of interest, including amino acid sequence, structure and interaction partners of many oncogenic proteins. Peptides can be designed to inhibit these interactions by means of sequence from the interaction domain. Thus, BPs are easily produced, and their sequence is easily modified using chemical synthesis or molecular biology techniques [50]. Proteins and peptides may act directly in the intestinal tract or via receptors and cell signaling pathways in the gut because most BPs are not absorbed in the intestinal tract [8]. Although intestinal absorption of di- and tri-peptides has been described, researchers have yet to clarify how BPs with high molecular weight move across of intestinal epithelium and which the action mechanisms of those peptides to induce specific effects against cancer cells are [2,7]. Human peptide transporter 1 (hPepT1) and 2 (hPepT2), two human dipeptide and tri-peptide specific intestinal membrane transporters, have been identified and extensively functionally characterized. hPepT1 is expressed in the small intestine, proximal tubules of the kidney, lysosomes of liver and pancreatic and renal cells; whereas hPepT2 is expressed in proximal tubules, brain, lungs and mammary glands. hPepT1 is constituted by 707-710 amino acid residues while hPepT2 is constituted by 729 . Both have several putative glycosylation phosphorylation sites, and it has been suggested that these transporters are constituted by 12 transmembrane domains, with both the $\mathrm{C}$ - and $\mathrm{N}$-terminal localized inside the cell. Di-peptides/tri-peptides and peptide-mimetic drug molecules resistant to enzymatic degradation in the cytosol are suggested to be transported by a saturable transport system that is yet to be identified [51].

Anticancer therapy is effective depending on stage and type of cancer but is expensive and extremely toxic to patients. For that reason, there is an urgent need for new research on cheap and non-toxic anticancer treatments. In this context, anticancer peptides are an alternative to drugs (small molecules) traditionally used in cancer treatments. These fragments of proteins induce cell death by different mechanisms, like apoptosis, broken tubulin-microtubule equilibrium, or inhibiting angiogenesis [52]. The diversity of peptides used in anticancer therapy has increased in the last years, given that small peptides, which have been observed to contain the motif Glutamine-Asparagine-Serine, are Ras-Raf (protein receptors involved in cancer pathways) interaction inhibitors. There is also a lot of interest in peptides that can target tumor cells with high specificity, as the Arginine-Glycine-Aspartic acid (RGD) motif, which shows high affinity to integrins [29]. Some commercial peptides, as somatostatin and bombesin, can specifically target Luteinizing Hormone-Releasing Hormone (LH-RH), bombesin/gastrin-releasing peptide and somatostatin receptors-2 and 5 [53].
Lunasin uses the action mechanism with RGD sequence to internalize cancer cells, causing apoptosis in different cancer cells lines [29]. Similarly, arginine-rich Cell-Penetrating Peptides (CPP's), including Tat from human immunodeficiency virus and oligoarginine derived from 8-12 arginine residues, have been reported to efficiently penetrate various types of cells. The conjugation with CPP's can be used to deliver bioactive molecules, including proteins, nucleic acids, and nanoparticles, into cells. That is why CPP's are promising vehicles for intracellular delivery [54]. Also, a recent study reported that lunasin inhibited colony formation by isolated melanoma of a small population of Cancer-Initiating Cells (CICs) in soft agar and reduced oncosphere formation in vitro and substantially inhibited tumor growth in mouse xenografts. Using mechanistic studies, the study revealed that lunasin treatment of isolated melanoma CICs induced the expression of the melanocyte-associated differentiation markers Tyrosinase and Microphthalmia associated Transcription Factor concomitant with reduced expression of the stemness factor NANOG, involved in migration, invasion, and dedifferentiation of melanoma cells. For the first time, the researchers reported that Lunasin has a significant therapeutic activity against melanoma by specifically targeting melanoma $\mathrm{CICs}$, and inducing a more differentiated non-CIC phenotype. This study showed that lunasin may represent a novel therapeutic option for both chemo-resistant and advanced metastatic melanoma management [55].

Additionally, a study reported by Dia, et al. [56] described that the concentration of lunasin in plasma, as determined by an enzyme-linked immunosorbent assay, ranged in the various subjects (men) from 50.2 to 110.6 $\mathrm{ng} / \mathrm{mL}$ of plasma for blood taken at $30 \mathrm{~min}$ and from 33.5 to $122.7 \mathrm{ng} / \mathrm{mL}$ of plasma for blood with drawn $1 \mathrm{~h}$ after ingestion on day 5 . The author estimated an average of $4.5 \%$ absorption of lunasin from the total lunasin ingested from $50 \mathrm{~g}$ of soy protein. So, bioactive peptide absorption remains an interesting field to generate investigation.

Cancer Protein and Peptides Database (Cancer PPD) is a databank that provides detailed information to experimentally verify anticancer peptides and proteins based on published articles and patents. This database includes information on sequence, structures, and action mechanisms, depending on the structure, length, hydrophobicity and specific characteristics of each peptide. Then, this database can be useful to design, find and report new peptides and proteins with anticancer activity [57]. Most of the anticancer peptides that are active against tumor cells adopt either a bioactive helical conformation at the cell surface or a $\beta$-sheet structure prior to engaging the membrane (Figure 2). Some of them, however, fold only at the surface of cancer cells and acquires a $\beta$-sheet structure that disrupts the cell membrane via pore formation [58]. Figure 2 shows 


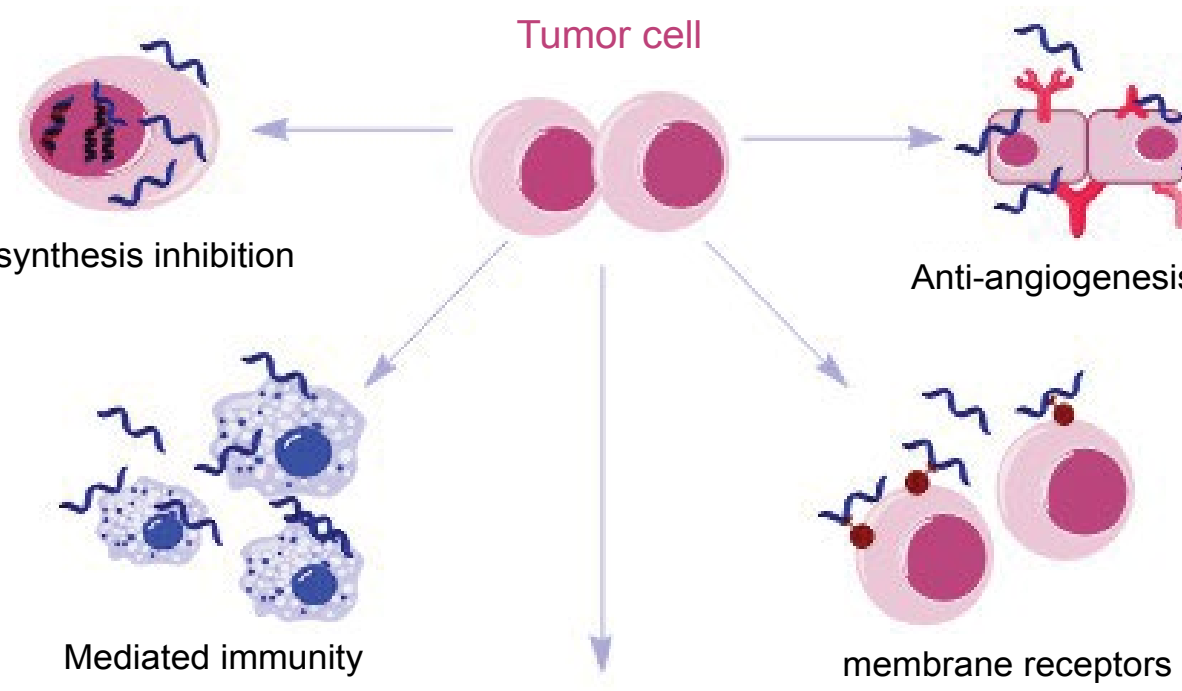

Membranolytic mode of action

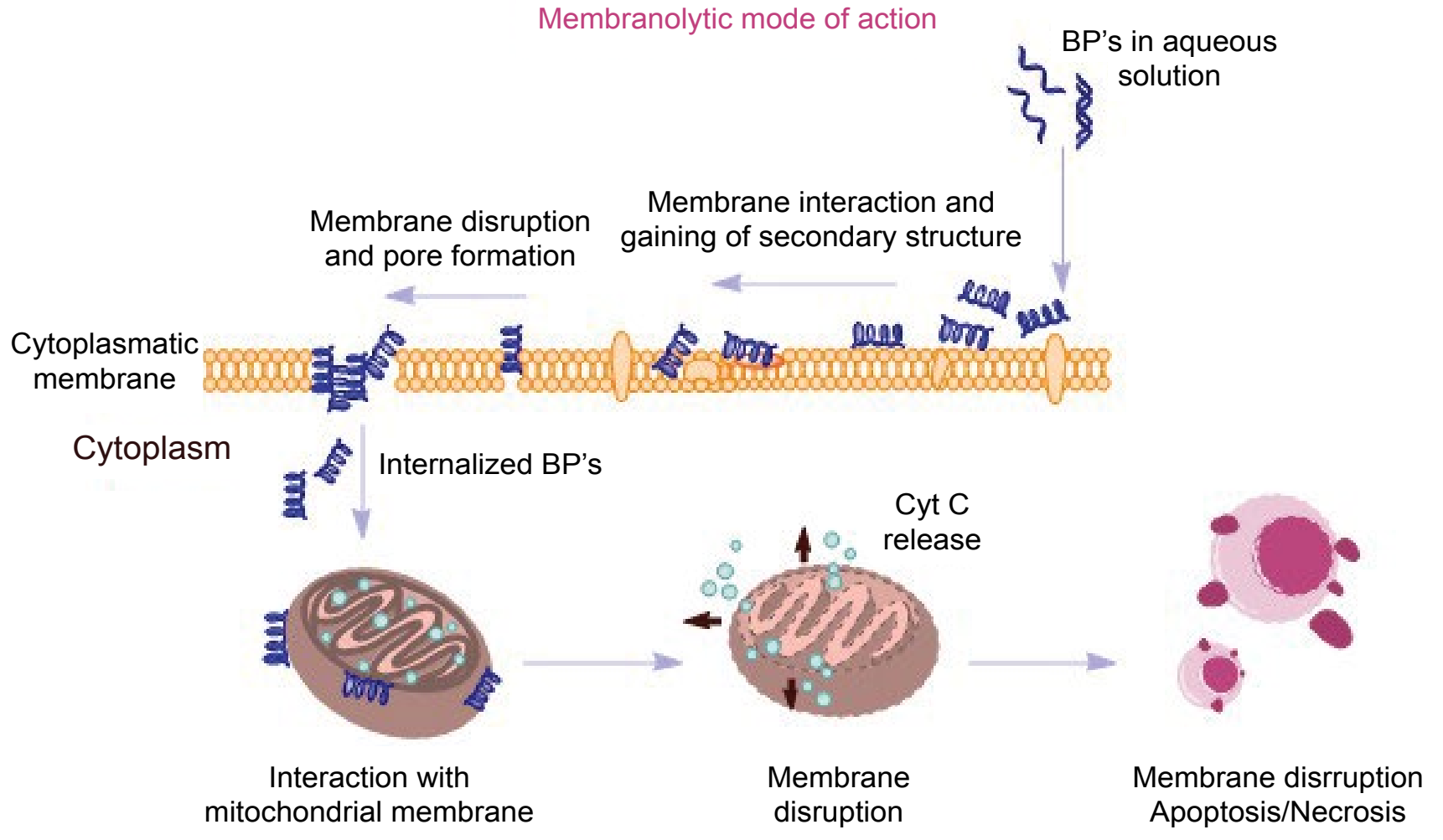

Figure 2: Action mechanisms from BPs, non-membranolytic and membranolytic modes of action $[57,58]$.

the modes of action of BPs which may involve alternative pathways, such as mediated immunity, hormonal receptors, DNA synthesis inhibition and anti-angiogenic effects [58].

\section{Anticancer Peptide Formulations as Commer- cial Drugs}

The nutraceutical industry has harnessed the potential of anticancer peptides. In 2013, RELIV-a Nutritional Company - acquired exclusive rights to the patented lunasin technology behind Luna Rich $\mathrm{X}^{\mathrm{TM}}$, a concentrated lunasin extract from soybean. According to RELIV, this peptide is commercialized as the first dietary ingredient identified to affect gene expression and promote optimal health by epigenetic mechanisms. In addition, there are many studies that have demonstrated the activity of lunasin to prevent cancer both in vivo and in vitro [59].

The identification and development of novel BPs will provide opportunities for cancer prevention and treatment. Legume-derived peptides are a class of anticancer agents that could specifically target cancer cells with a lower toxicity to normal tissues [60]. Conventional anticancer therapies have low specificity and often cause severe side effects. Consequently, more efforts should be made to improve their therapeutic potentials. We should continue to explore novel legume-derived BPs with anticancer properties and enhance the tumor targeting capacity [60]. The potential of peptide drugs is yet to be fully explored. However, the recent advances in proteomics and peptidomics bring us closer to the 'The Bioactive Peptide Era' [60]. 


\section{Conclusions}

The legume family is an excellent food source of bioactive compounds which, in turn, represent an effective source for cancer therapeutics. BPs could be directly consumed or incorporated as ingredients in functional foods, dietary supplements and even pharmaceuticals, with the purpose of delivering specific health benefits as anticancer agents. Peptides are a novel class of anticancer agents that could specifically target cancer cells with lower toxicity to normal tissues, which will offer new opportunities for cancer prevention and treatment. It is necessary to develop more research to find new peptide sequences and their action mechanisms that are suitable for human consumption and commercialized by the pharmaceutical industry. There is few information on the contribution of bioactive peptides to the formation of AGEs after their absorption and the effect they may have in cancer treatments.

\section{References}

1. Torre LA, Bray F, Siegel RL, Ferlay J, Lortet-Tieulent J, et al. (2015) Global Cancer Statistics, 2012. CA Cancer J Clin 65: 87-108.

2. Kuppusamy P, Yusoff MM, Maniam GP, Ichwan SJ, Soundharrajan I, et al. (2014) Nutraceuticals as potential therapeutic agents for colon cancer: a review. Acta Pharm Sin B 4: 173-181.

3. Danquah MK, Agyei D (2012) Pharmaceutical applications of bioactive peptides. OA Biotechnology 1: 5 .

4. Carbonaro M, Maselli P, Nucara A (2014) Structural aspects of legume proteins and nutraceutical properties. Food Research International 76: 19-30.

5. Hannu Korhonen, Anne Pihlanto (2006) Bioactive peptides: Production and functionality. International Dairy Journal 16: 945-960.

6. López-Barrios L, Gutiérrez-Uribe JA, Serna-Saldívar SO (2014) Bioactive Peptides and Hydrolysates from Pulses and Their Potential Use as Functional Ingredients. J Food Sci 79: 273-283.

7. Sharma S, Singh R, Rana S (2011) Bioactive Peptides: A Review. Int J Bioautomation 15: 223-250.

8. Möller NP, Scholz-Ahrens KE, Roos N, Schrezenmeir J (2008) Bioactive peptides and proteins from foods: Indication for health effects. Eur J Nutr 47: 171-182.

9. Minkiewicz P, Dziuba J, Iwaniak A, Dziuba M, Darewicz M (2008) BIOPEP Database and Other Programs for Processing Bioactive Peptide Sequences. J AOAC Int 91: 965-980.

10. Lei Z, Dai X, Watson BS, Zhao PX, Sumner LW (2011) A legume specific protein database (LegProt) improves the number of identified peptides, confidence scores and overall protein identification success rates for legume proteomics. Phytochemistry 72: 1020-1027.

11. Drago SR, Franco-Miranda H, Cian RE, Betancur-Ancona D, Chel-Guerrero L (2016) Bioactive Properties of Phaseolus luntatus (Lima Bean) and Vignaunguiculata (Cowpea) Hydrolyzates Incorporated into Pasta. Residual Activity after Pasta Cooking. Plant Foods Hum Nutr 71: 339-345.

12. Luna-Vital DA, Mojica L, González de Mejía E, Mendoza S, Loarca-Piña G (2015) Biological potential of protein hydro- lysates and peptides from common bean (Phaseolus vulgaris L.): A review. Food Research International 76: 39-50.

13. León-Espinosa E, Sánchez-Chino X, Garduño-Siciliano L, Álvarez-González RI, Dávila-Ortiz G, et al. (2016) Hypocholesterolemic and Anticarcinogenic Effect of Vicia faba Protein Hydrolyzates. Nutr Cancer 68: 856-864.

14. Sanjukta S, Rai AK (2016) Production of bioactive peptides during soybean fermentation and their potential health benefits. Trends in Food Science and Technology 50: 1-10.

15. Mora-Escobedo R, Robles-Ramírez Mdel C, Ramón-Gallegos E, Reza-Alemán R (2009) Effect of protein hydrolysates from germinated soybean on cancerous cells of the human cervix: An In Vitro study. Plant Foods Hum Nutr 64: 271-278.

16. Limón RI, Peñas E, Torino MI, Martínez-Villaluenga C Dueñas M, et al. (2015) Fermentation enhances the content of bioactive compounds in kidney bean extracts. Food Chem 172: 343-352.

17. Huang X, Cai W, Xu B (2014) Kinetic changes of nutrients and antioxidant capacities of germinated soybean (Glycine max L.) and mung bean (Vignaradiata L.) with germination time. Food Chem 143: 268-276.

18. Robles-Ramírez Mdel C, Ramón-Gallegos E, Reyes-Duarte FJ, Mora-Escobedo R (2012) Effect of Germinated Soy Protein on the Growth of HeLa Cervical Cancer Cells in Female Athymic Mice. Nutr Cancer 64: 1261-1268.

19. Montoya-Rodríguez A, Milán-Carrillo J, Dia VP, Reyes-Moreno C, González de Mejía E (2014) Pepsin-pancreatin protein hydrolysates from extruded amaranth inhibit markers of atherosclerosis in LPS-induced THP-1 macrophages-like human cells by reducing expression of proteins in LOX-1 signaling pathway. Proteome Sci 12: 30.

20. Hannu Korhonen, Anne Pihlanto-Leppäla, Pirjo Rantamäki, Tuomo Tupasela (1998) Impact of processing on bioactive proteins and peptides. Trends Food Science and Technology 9: 307-319.

21. Bao JM, He MY, Liu YW, Lu YJ, Hong YQ, et al. (2015) AGE/RAGE/Akt pathway contributes to prostate cancer cell proliferation by promoting $\mathrm{Rb}$ phosphorylation and degradation. Am J Cancer Res 5: 1741-1750.

22. Bierhaus A, Humpert PM, Morcos M, Wendt T, Chavakis $\mathrm{T}$, et al. (2005) Understanding RAGE, the receptor for advanced glycation end products. J Mol Med 83: 876-886.

23. Turner DP (2015) Advanced Glycation End-Products: A Biological Consequence of Lifestyle Contributing to Cancer Disparity. Cancer Res 75: 1925-1929.

24. Sánchez-Chino X, Jiménez-Martínez C, Dávila-Ortiz G, Álvarez-González I, Madrigal-Bujaidar E (2015) Nutrient and nonnutrient components of legumes, and its chemopreventive activity: a review. Nutr Cancer 67: 401-410.

25. Wenyi Wang, Elvira Gonzalez De Mejia (2005) A new frontier in soy bioactive peptides that may prevent age-related chronic diseases. CRFSFS 4: 63-78.

26. Hartman TJ, Albert PS, Zhang Z, Bagshaw D, Kris-Etherton PM, et al. (2010) Consumption of a legume-enriched, low-glycemic index diet is associated with biomarkers of insulin resistance and inflammation among men at risk for colorectal cancer. J Nutr 140: 60-67.

27. Wang Y, Wang Z, Fu L, Chen Y, Fang J (2013) Legume Consumption and Colorectal Adenoma Risk: A Meta-Analysis of Observational Studies. PLoS One 8: e67335.

28. Alezandro MR, Granato D, Lajolo FM, Genovese MI (2011) 
Nutritional aspects of second generation soy foods. J Agric Food Chem 59: 5490-5497.

29. de Mejia EG, Wang W, Dia VP (2010) Lunasin with an arginine-glycine-aspartic acid motif, causes apoptosis to L1210 leukemia cells by activation of caspase-3. Mol Nutr Food Res 54: 406-414.

30. Agyei D (2015) Bioactive Proteins and Peptides from Soybeans. Recent Pat Food Nutr Agric 7: 100-107.

31. Marcela GM, Eva RG, Del Carmen RM, Rosalva ME (2016) Evaluation of the Antioxidant and Antiproliferative Effects of Three Peptide Fractions of Germinated Soybeans on Breast and Cervical Cancer Cell Lines. Plant Foods Hum Nutr 71: 368-374.

32. Galvez AF, Chen N, Macasieb J, de Lumen BO (2001) Chemopreventive property of a soybean peptide (Lunasin) that binds to deacetylated histones and inhibits acetylation. Cancer Res 61: 7473-7478.

33. Luna Vital DA, González de Mejía E, Dia VP, Loarca-Piña $G$ (2014) Peptides in common bean fractions inhibit human colorectal cancer cells. Food Chem 157: 347-355.

34. Fang EF, Pan WL, Wong JH, Chan YS, Ye XJ, et al. (2011) A new Phaseolus vulgaris lectin induces selective toxicity on human liver carcinoma Hep G2 cells. Arch Toxicol 85: 1551-1563.

35. Jian Sun, Hexiang Wang, Tzi Bun Ng (2010) Trypsin isoinhibitors with antiproliferative activity toward leukemia cells from Phaseolus vulgaris cv "White Cloud Bean". J Biomed Biotechnol.

36. Roy F, Boye Jl, Simpson BK (2010) Bioactive proteins and peptides in pulse crops: Pea, chickpea and lentil. Food Research International 43: 432-442.

37. Magee PJ, Owusu-Apenten R, McCann MJ, Gill Cl, Rowland IR (2012) Chickpea (Cicer arietinum) and Other Plant-Derived Protease Inhibitor Concentrates Inhibit Breast and Prostate Cancer Cell Proliferation In Vitro. Nutr Cancer 64: 741-748.

38. Kumar S, Kapoor V, Gill K, Singh K, Xess I, et al. (2014) Antifungal and Antiproliferative Protein from Cicer arietinum : A Bioactive Compound against Emerging Pathogens. Biomed Res Int 2014: 387203.

39. Rubio LA, Pérez A, Ruiz R, Guzmán MÁ, Aranda-Olmedo I, et al. (2014) Characterization of pea (Pisum sativum) seed protein fractions. J Sci Food Agric 94: 280-287.

40. Barać MB, Pešić MB, Stanojević SP, Kostić AŽ, Čabrilo SB (2015) Techno-Functional Properties of Pea (Pisum sativum) Protein Isolates- a Review. APTEFF 46: 1-269.

41. Clemente A, Carmen Marín-Manzano M, Jiménez E, Carmen Arques M, Domoney C (2012) The anti-proliferative effect of TI1B, a major Bowman-Bowman Birk isoinhibitor from pea (Pisum sativum L.), on HT29 colon cancer cells is mediated through protease inhibition. $\mathrm{Br} J$ Nutr 108: S135-S144.

42. Abu-Reidah IM, Arráez-Román D, Warad I, Fernández-Gutiérrez A, Segura-Carretero A (2017) UHPLC/MS2-based approach for the comprehensive metabolite profiling of bean (Vicia faba L.) by-products: A promising source of bioactive constituents. Food Res Int 93: 87-96.

43. Fang EF, Hassanien AA, Wong JH, Bah CS, Soliman SS, et al. (2011) Isolation of a new trypsin inhibitor from the Faba bean (Vicia faba cv. Giza 843) with potential medicinal applications. Protein Pept Lett 18: 64-72.

44. Ye XY, Ng TB (2002) A new peptidic protease inhibitor from Vicia faba seeds exhibits antifungal, HIV-1 reverse transcriptase inhibiting and mitogenic activities. J Pept Sci 8: 656-662.

45. Torino MI, Limón RI, Martínez-Villaluenga C, Mäkinen S, Pihlanto A, et al. (2013) Antioxidant and antihypertensive properties of liquid and solid state fermented lentils. Food Chem 136: 1030-1037.

46. Caccialupi P, Ceci LR, Siciliano RA, Pignone D, Clemente A, et al. (2010) Bowman-Birk inhibitors in lentil: Heterologous expression, functional characterisation and anti-proliferative properties in human colon cancer cells. Food Chem 120: 1058-1066.

47. van de Noort M (2017) Chapter 10-Lupin An Important Protein and Nutrient Source. Sustain Protein Sources, 165183.

48. Petterson DS (2016) Lupin: Overview. Encycl Food Grains, 280-286.

49. Millán-Linares María del Carmen, Bermúdez Beatriz, Yust María del Mar, Millán Francisco, Pedroche Justo (2014) Anti-inflammatory activity of lupine (Lupinus angustifolius L.) protein hydrolysates in THP-1-derived macrophages. Journal of Functional Foods 8: 224-233.

50. Bidwell GL 3rd, Raucher D (2009) Therapeutic peptides for cancer therapy. Part I - peptide inhibitors of signal transduction cascades. Expert Opin Drug Deliv 6: 1033-1047.

51. Santos S, Torcato I, Castanho MA (2012) Biomedical applications of dipeptides and tripeptides. Biopolymers 98: 288-293.

52. Kim EK, Kim YS, Hwang JW, Lee JS, Moon SH, et al. (2013) Purification and characterization of a novel anticancer peptide derived from Ruditapes philippinarum. Process Biochemistry 48: 1086-1090.

53. Schally AV, Nagy A (2004) Chemotherapy targeted to cancers through tumoral hormone receptors. Trends Endocrinol Metab 15: 300-310.

54. Nakase I, Konishi Y, Ueda M, Saji H, Futaki S (2012) Accumulation of arginine-rich cell-penetrating peptides in tumors and the potential for anticancer drug delivery in vivo. J Control Release 159: 181-188.

55. Chris Shidal, Numan Al-Rayyan, Kavitha Yaddanapudi, Keith R Davis (2016) Lunasin is a novel therapeutic agent for targeting melanoma cancer stem cells. Oncotarget 7 : 84128-84141.

56. Dia VP, Torres S, De Lumen BO, Erdman JW Jr, De Mejia EG (2009) Presence of Lunasin in Plasma of Men after Soy Protein Consumption. J Agric Food Chem 57: 1260-1266.

57. Tyagi A, Tuknait A, Anand P, Gupta S, Sharma M, et al. (2015) CancerPPD: A database of anticancer peptides and proteins. Nucleic Acids Res 43: 837-843.

58. Gaspar D, Veiga AS, Castanho MA (2013) From antimicrobial to anticancer peptides. A review. Front Microbiol 4: 294.

59. Hernández-Ledesma B, Hsieh CC, de Lumen BO (2009) Lunasin, a novel seed peptide for cancer prevention. Peptides 30: 426-430.

60. Wu D, Gao Y, Qi Y, Chen L, Ma Y, et al. (2014) Peptide-based cancer therapy: Opportunity and challenge. Cancer Lett 351: 13-22.

61. de Mejia EG, Dia VP (2009) Lunasin and lunasin-like peptides inhibit inflammation through suppression of NF-KB pathway in the macrophage. Peptides 30: 2388-2398. 
62. Kim SE, Kim HH, Kim JY, Kang YI, Woo HJ, et al. (2000) Anticancer activity of hydrophobic peptides from soy proteins. Biofactors 12: 151-155.

63. Kwan S, Bun T (2011) Apoptosis of human breast cancer cells induced by hemagglutinin from Phaseolus vulgaris cv. Legumisecchi. Food Chem 126: 595-602.

64. Fang EF, Lin P, Wong JH, Tsao SW, Ng TB (2010) A lectin with anti-HIV-1 reverse transcriptase, antitumor, and nitric oxide inducing activities from seeds of Phaseolus vulgaris cv. Extralong Autumn Purple Bean. J Agric Food Chem 58: 2221-2229.

65. Zhaohui Xue, Haichao Wen, Lijuan Zhai, Yanqing Yu, Yanni Li, et al. (2015) Antioxidant activity and anti-proliferative effect of a bioactive peptide from chickpea (Cicer arietinum L.). Food Research International 77: 75-81. 